sinds, zeg, halverwege de jaren 1970. Een mogelijke verklaring zou, zoals elders door mij is betoogd, kunnen zijn dat deze toenmaals oorspronkelijke analyse geleidelijk aan niet meer goed paste in het moderne economisch-theoretische denken ${ }^{1}$. Gewoon op een verkeerd spoor zit de schrijver als hij meent dat het onderscheid tussen monetair conditiemodel en causaal model een zeer belangrijk aspect zou zijn van de monetaire beleidsanalyse van de Bank. Voor zover ik heb kunnen nagaan is dit onderscheid eerst in de jaren 1970 expliciet gemaakt in een aantal min of meer theoretische beschouwingen maar heeft deze theoretische en mijns inziens betwistbare verfijning geen zichtbare rol gespeeld in de beleidsanalyse. Ondanks zijn warm pleidooi voor dit onderscheid op bladzijden 163-164 slaagt Schotsman er niet in de doelmatigheid van deze abstracte verfijning aannemelijk te maken. Eigenlijk valt, zo vrees ik, de breedvoerige behandeling van de monetaire analyse van de Bank wat buiten het eigenlijke onderwerp van dit boek. Het wekt ook verwondering dat de afbakening van het liquiditeitsbegrip, voor het monetaire hoeveelheidsbeleid van de centrale bank een kernvraagstuk, door Schotsman wordt besproken zonder ook maar de minste aandacht te schenken aan op de Bank terzake verrichte en gepubliceerde studies. Vooralsnog beschouw ik dit ontbreken en de weinig overtuigende aandacht voor de monetaire analyse vooral als de onrijpe kantjes van een in vele andere opzichten evenwichtig boek. Wellicht verraadt zich hierin de niet-economische herkomst van de schrijver.

De voorgaande kritische aantekeningen nemen intussen niet weg dat naar mijn oordeel Schotsmans boek, en dit is een onmiskenbare verdienste, gevoel bijbrengt voor de groei en vermaatschappelijking van de Bank en de evolutie van inhoud en draagwijdte van de geldpolitiek sinds 1863. Het laat ook zien dat de belangstelling van het parlement voor de Bank aan opmerkelijke wisselingen onderhevig is en dat monetaire politiek meestal wordt gezien als een technische aangelegenheid. Veel belangstelling, zo leert dit boek, heeft het parlement steeds aan de dag gelegd voor de organisatievorm van de Bank. Met de Bankwet van 1948 werd een duidelijke positie gekozen. Tot 1948 stond het de wetgever vrij ook aan anderen dan de Bank het recht op uitgifte van bankbiljetten te geven. Het boek laat echter zien dat sinds ongeveer 1825 'geen zinnig mens er meer over dacht om naast DNB ook aan anderen het recht toe te kennen bankbiljetten te emitteren'. Deze passage herinnerde mij aan een interessant strijdpunt uit de banktheorie waarin onder andere, bijvoorbeeld door de neo-Oostenrijker Hayek, wordt gepleit voor elkaar beconcurrerende centrale banken binnen één land, opdat aldus gezonder geld zou ontstaan. Ik doel daarbij op de zienswijze van de zogenaamde 'free banking' benadering. Schotsman rept niet van dit intellectueel interessante maar praktisch wellicht zonder groot belang zijnde strijdpunt. Dit is jammer omdat het interessant zou zijn geweest dit puur academische idee in zijn historische context behandeld te zien. Hoe dan ook, dit proefschrift is een mooi boek en belicht de Bank vanuit een nogal eens vergeten gezichtspunt.

M. M. G. Fase

1 Vgl. M. M. G. Fase, 'Dutch monetarism in retrospect' (referaat voor de bijeenkomst van de 'American Society of the history of economics', Harvard Business School, 20-22 juni 1987, mimeo).

J. M. M. J. Clerx, Nederland en de liberalisatie van het handels- en betalingsverkeer (19451958) (Dissertatie Tilburg, NIBE-publikatiereeks LIX; Groningen: Wolters-Noordhoff, 1986,278 blz., f45,-, ISBN 900120150 4). 
In de huidige macro-economie en het daarmee verwante economische beleid is de aandacht vooral gericht op globale monetaire en fiscale beleidsmaatregelen, op begrotings- en op loonpolitiek. De handelspolitiek daarentegen komt veel minder ter sprake. Dit is vermoedelijk mede een gevolg van het feit dat de handelspolitiek buiten de thans geldende economisch-theoretische belangstellingssfeer ligt en in de beleidssfeer een zeer ondergeschikte plaats inneemt. Dat dit in het recente verleden anders was vormt wellicht de voornaamste boodschap van het boek van Clerx, dat in december 1986 als proefschrift diende aan de Katholieke Universiteit Brabant.

De studie van Clerx biedt een minutieus verslag van de Nederlandse handelspolitiek in de naoorlogse jaren 1945-1958. De doelstelling van dit beleid was de handel te bevrijden van kwantitatieve beperkingen, de tariefbarrières te verminderen en de overige vormen van handelsbescherming zoveel mogelijk te elimineren. Nauw verbonden met deze handelsliberalisatie was de vrijmaking van het internationale betalingsverkeer, wat een noodzakelijke voorwaarde is voor handelsliberalisatie. Het boek van Clerx verhaalt met accuratesse en oog voor ambtelijk en administratief detail van dit boeiende proces waarin het behouden van een stevige internationale onderhandelingspositie een voortdurend aanwezige constante blijkt te zijn. Geschetst wordt de Nederlandse uitgangssituatie van 1945 met een streng gereglementeerd deviezenbeleid, bilaterale handelsakkoorden en de noodzaak de schaarse deviezenvoorraad zo doelmatig mogelijk te gebruiken voor de invoer van de voor de wederopbouw van Nederland meest wezenlijke kapitaalgoederen. Verhaald wordt ook van de grote betekenis van de Marshall-hulp sinds 1948, en de rol van de OEES (Organisatie van Europese Economische Samenwerking) - welke later, maar dit valt buiten het beschreven tijdvak, de OESO zou gaan heten - als instrument voor liberalisatie en verbreding tot multilaterale samenwerking op gebied van handel en betalingsverkeer. Voorts worden ontstaan en groei getekend van geheel verschillende instellingen als Europese Betalings Unie - EBU - in 1950 en Benelux in 1947, die beide gelden als wegbereiders voor een Europa met vrijhandel en economische samenwerking. Een thans vergeten lichaam als de Europese Gemeenschap voor Kolen en Staal - EGKS - , gesticht in 1951, wordt ten tonele gevoerd als succesrijk voorbeeld van een verticale, dat wil zeggen sectorsgewijze, handelsliberalisatie. Zeer uitvoerig wordt de weg naar volledige convertibiliteit of inwisselbaarheid van de verschillende geldsoorten getekend, een weg vol met praktische problemen, tactische bewegingen en principiële tegenstellingen, waarachter dikwijls uiteenlopende nationale economische belangen schuil gaan. We zien de Europese Monetaire Overeenkomst - EMO - en het Europese Monetaire Fonds tot stand komen in 1955 maar vervolgens eerst eind 1958 in werking treden omdat de economische situatie in de tussenliggende jaren met name Frankrijk, VS en de Bondsrepubliek weerhield van feitelijke invoering van de EMO en daarmede van de externe convertibiliteit. De invoering van de EMO betekende liquidatie van de EBU en voltooiing van een multilateraal betalingsstelsel voor het internationale handelsverkeer. Het verhaal over dit proces van handelsliberalisatie wordt door de schrijver vaak afgewisseld met interessante details zoals de tegenstelling tussen de toenmalige ministers van Financiën en Economische Zaken over het tempo van de liberalisatie.

Naast lof is er echter ook kritiek op deze studie mogelijk. Ik noem twee punten van kritiek. Het eerste is het geheel ontbreken van een economisch-theoretisch kader voor de probleemstelling van deze studie. Dit wekt, althans bij deze recensent, bevreemding. Het streven naar vrijhandel is immers niet alleen een historisch gezien oude Nederlandse traditie, maar binnen de economische theorie bezit vrijhandel sinds de dagen van Adam Smith en Ricardo een 
op zeer fijnzinnige wijze uitgewerkte intellectuele fundering. Het ware wenselijk geweest dat, bij wijze van situering van de probleemstelling, tenminste enige aandacht was geschonken aan dit ruimere economisch-theoretische verband. Economische geschiedschrijving, zo kan men menen, ontleent zijn betekenis niet alleen aan het naar voren halen van economische feiten maar ook aan derzelver interpretatie in het licht van de beschikbare economische redeneringen. Welnu, op dit punt schiet het boek tekort en blijft het steken in een overigens op intelligente wijze opgediende aaneenschakeling van handelspolitieke feiten uit de naoorlogse jaren 1945-1958. Mijn tweede kritiekpunt betreft de presentatie van de feiten voor zover deze neerslaan in cijfers en tabellen. Het boek bevat een grote rijkdom, ik telde er 40, aan tabellen met gegevens over betalingsbalanssaldo's, deviezenreserves en prijsindexen van in- en uitvoer. De lezer krijgt echter allengs het gevoel dat hij bepaalde informatie al eens eerder heeft gezien in dit boek. Terugbladeren leert dat dit ongeveer ook zo is. Nog vervelender is de broksgewijze presentatie van de cijfers, die soms weinig systematisch is. Het ware wenselijk geweest als de schrijver zich wat meer moeite had gegeven meer systematiek te brengen in zijn tabellen. Hierdoor zou een grotere eenheid zijn verkregen en zou de cijfermatige achtergrond aan illustratieve en verklarende waarde hebben gewonnen. Kortom, de informatieverstrekking via tabellen, en voor de economisch-historicus is dit een niet onbelangrijk hulpmiddel, is in dit boek rommelig en laat veel te wensen over. Dat is jammer en ware gemakkelijk te voorkomen geweest door eens goed na te gaan hoe zoiets wordt aangepakt in andere publikaties. Handig is in elk geval de lijst met afkortingen voorafgaande aan bladzijde 1 , in het bijzonder voor de lezer die niet erg thuis is in de vele acroniemen, die in de wereld van de handelspolitiek gemeengoed zijn.

Mijn bezwaren nemen niet weg dat Clerx een informatief en interessant boek heeft geschreven over een zeer speciaal onderwerp uit de naoorlogse herstelperiode. Hij heeft zich daarbij uitvoerig verdiept in het ambtelijk bronnenmateriaal en hiervan met grote accuratesse verslag gedaan.

M. M. G. Fase 


\title{
De Gentse immobiliënmarkt en de economische trend, 1590-1640 *
}

\author{
JOHAN DAMBRUYNE
}

\section{PROBLEEMSTELLING}

De meeste historici zijn het er momenteel over eens dat de zeventiende eeuw in haar geheel niet zonder meer als een 'ongelukseeuw' mag worden beschouwd voor de Zuidelijke Nederlanden '. Algemeen wordt aanvaard dat het pas na het midden van de eeuw is dat de seculaire contractie zich in de Nederlandse economie heeft gemanifesteerd $^{2}$. Nochtans weet men tot dusver weinig, met uitzondering van Antwerpen ${ }^{3}$, over de economische conjunctuur in de Zuidnederlandse steden tijdens deze eeuw. Doel van dit artikel is de economische trend van de stad Gent tussen circa 1590-1640 te analyseren, in de hoop hierdoor de bestaande lacune in het historisch onderzoek enigszins aan te vullen. Er werd gekozen voor Gent, 1 omdat deze stad tijdens de zeventiende eeuw, na Antwerpen, de grootste was van de Spaanse Nederlanden ${ }^{4}$ en 2 omdat de studie van D. van Ryssel heeft uitgewezen dat de Gentse huishuurprijzen gedurende deze eeuw een spectaculaire stijging hebben gekend ${ }^{5}$.

Aangezien de economie zich het best in cijfers laat uitdrukken, werd geopteerd voor een kwantitatieve aanpak. Iedereen weet nochtans dat er voor het Ancien Régime weinig cijfermateriaal voorhanden is, dat toestaat om een nauwkeurig beeld te geven van de algemene economische conjunctuur van een stad. Immers, de meeste statistische bronnen die beschikbaar zijn, belichten slechts deelsectoren van het economisch leven. De 'schepenregisters' vormen echter een uitzondering ${ }^{6}$.

* Onze oprechte dank gaat uit naar prof. dr. H. Soly en prof. dr. M. Baelde voor hun kritische opmerkingen. Gebruikte afkortingen: SAG: Stadsarchief te Gent; 301: Jaarregisters; 303: Registers 'vrij huis, vrij erve'; 330: Staten van goederen; 333: Akten en contracten; 400: Stadsrekeningen.

1 Het doorbreken van de mythe der 'ongelukseeuw' is vooral de verdienste geweest van J. A. van Houtte: 'Onze zeventiende eeuw 'Ongelukseeuw'?', Mededelingen der Koninklijke Vlaamse Academie, Klasse der Letteren, XIV, nr. 8 (1953); Essays on Medieval and Early Modern Economy and Society (Leuven, 1977); 'Economie et société aux Pays-Pas à l'époque de Rubens', Bulletin de l'Institut historique belge de Rome, XLVUI-XLIX (1979) 189-205.

2 A. M. van der Woude, 'De 'Nieuwe Geschiedenis' in een nieuwe gedaante. Inleiding op de delen 5 tot en met 9', in: Algemene Geschiedenis der Nederlanden (Haarlem, 1980) V, 17-34.

3 J. A. van Houtte, 'Déclin et survivance d'Anvers(1550-1700)\ in: Studi in onore di Amintore Fanfani (Milaan, 1962) V, 705-726; W. Brulez, 'Anvers de 1585 à 1650', Vierteljahrschrift für Sozial- und Wirtschaftsgeschichte, LIV ( 1967) 75-99; R. Baetens, De nazomer van Antwerpens welvaart. De diaspora en het handelshuis De Groote tijdens de eerste helft der 17de eeuw (Brussel, 1976).

4 E. Hélin, 'Demografische ontwikkeling van de Zuidelijke Nederlanden, 1500-1800', in: Algemene Geschiedenis der Nederlanden (Haarlem, 1980) V, 175, 179-180.

5 De nominale huishuurindex steeg tussen 1590 en 1678 aanhoudend van 100 tot 413 . De prijsstijging tijdens de zestiende eeuw was minder scherp: de index steeg van 100 in 1500 tot 260 in 1584. D. van Ryssel, De Gentse huishuren lussen 1500 en 1795. Bijdrage tol de kennis van de konjunktuur van de stad (Brussel, 1967) $101-105$.

6 Het is pas vanaf de jaren zestig dat de aandacht werd gevestigd op de schepenregisters als bron voor kwantitatief economisch en sociaal onderzoek. J. A. van Houtte, 'Quantitative Quellen zur Geschichte des 